CIHM

Microfiche

Series

(Monographs)
ICMH

Collection de microfiches (monographies)

Canadien Institute for Historical Microreproductions / Institut canadien de microreproductions historiques
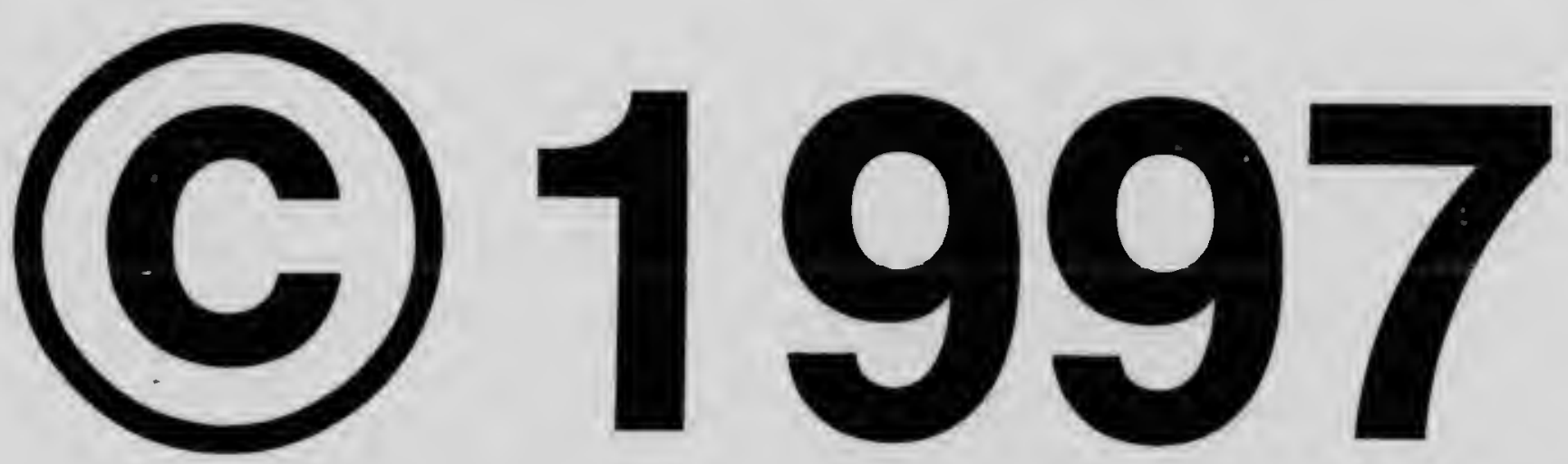


\section{Technical and Bibliographic Notes / Notes techniquєs et bibliographiques}

The Institute has attempted to obtaln the best original copy available for filming. Features of this copy which may be bibliographically unlque, which may alter any of the images In the reproduction, or whlch may significantly change the usual method of fllming are checked below.

Coloured covers /

Couverture de couleur

\section{Covers damaged /}

Couverture endommagée

Covers restored and/or laminated /

Couverture restaurée et/ou pelliculée

Cover title missing / Le titre de couverture manque

Coloured maps / Cartes géographiques en couleur

Coloured ink (i.e. other than blue or black) /

Encre de couleur (i.e. autre que bleue ou noire)

Coloured plates and/or illustrations /

Planches eVou illustrations en couleur

Bound with other material /

Relié avec d'autres documents

Only edition available /

Seule édition disponible

Tight binding may cause shadows or distortion along interior margin / La reliure serrée peut causer de l'ombre ou de la distorsion le long de la marge intérieure.

Blank leaves added during restorations may appear within the text. Whenever possible, these have been omitted from filming / II se peut que certaines pages blanches ajoutées lors d'une restauration apparaissent dans le texte, mais, lorsque cela était possible, ces pages n'ont pas été filmées.

Additional comments /

Commentaires supplémentaires:
L'Institut a microfilmé le melleur exemplalre qu'il lul a été possible de se procurer. Les détails de cet exem. plaire qul sont peut-être uniques du polnt de vue bibllographique, qui peuvent mo "fier une Image reproduite, ou qui peuvent exlger une modification dans la méthode normale de filmage sont indiqués ci-dessous.

\section{Coloured pages / Pages de couleur}

Pages damaged / Pages endommagérs

Pages restored and/or laminated /

Pages restaurées et/ou pelliculées

Pages discoloured, stained or foxed /

Pages décolorées, tachetées ou plquées

Pages detached / Pages détachées

\section{Showthrough / Transparence}

Quality of print varies I

Qualité inégale de l'impression

Includes supplementary material /

Comprend du matériel supplémentaire

Pages wholly or nartially obscured by errala slips, tissues, etc., have been refilmed to ensure the best possible image / Les pages totalement ou partiellement obscurcies par un feuillet d'errata, une pelure, etc., ont été filmées à nouveau de façon à obtenir la meilleure image possible.

Opposing pages with varying colouration or discolourations are filmed twice to ensure the best possible image / Les pages s'opposant ayant des colorations variables ou des décolorations sont filmées deux fois afin d'obtenir la meilleure image possible.

This ftem is flimed st the reduction ratlo checked below I

Ce document est films su taux de réduction Indiqui ch-dessous.

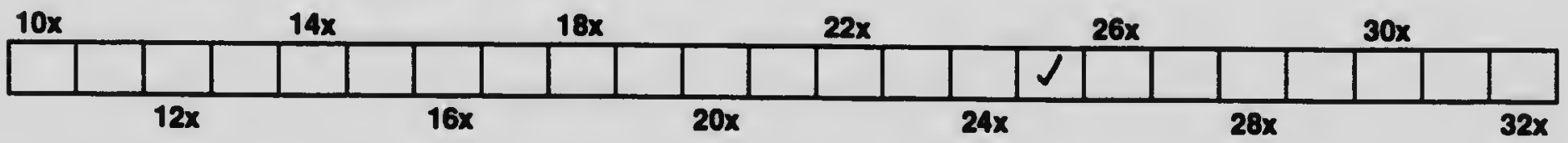


The copy filmed here has been reproduced thanks to the generosity of:

$$
\begin{aligned}
& \text { Library } \\
& \text { Agrieulture Canada }
\end{aligned}
$$

The images appearing here are the best quality possibie considering the condition and ieglbility of the original copy and in keeping with the fliming contract specifications.

Originai copies in printed paper covers are filmed beginning with the front cover and anding on the iast page with a printed or lilustrated impression, or the back cover when approprlate. Ali other original copies are filmed beginning on the first page with a printed or lliustrated impression, and ending on the last page with a printed or iliustrated impression.

The iast recorded frame on each microfiche shail contain the symbol $\rightarrow$ Imeaning "CONTINUED"), or the symbol $\nabla$ (meaning "END"). whichever appiles.

Maps, piates, charts, etc.. may be flimed at different reduction ratios. Those too iarge to be entirely inciuded in one exposure are filimed beginning in the upper loft hand corner, loft to right and top to bottom, as many frames as required. The foliowing diagrams iliustrate the method:
L'exempiaire filime fut reproduit grâce la génórosité do:

\section{Bibliothique \\ Agriculture Canade}

Les images suivantes ont ste reproduites avec io pius grand soin, compte tenu de ia condition ot de ia nettets de lexempiaire filimb, ot en conformits avec ies conditions du contrat de filmage.

Les exemplaires originaux dont ia couverture en papler est imprimbe sont filimb́s on commençant par ie premier piat et en terminant soit par la dernilere page qui comporte une empreinte d'impression ou d'iliustration, soit par le second plat, seion ie cas. Tous les autres exemplaires originaux sont filmbs en commençant par ia promitre page qui comporte une empreinte d'impression ou d'iliustration ot en terminant par la dernidre page qui comporte une teile empreinte.

Un des symboles sulvants apparaitra sur ia derniòre image de chaque microfich , seion le cas: le symbole $\rightarrow$ signifle "A SUIVRE", ie symbole $\nabla$ signifle "FIN".

Les cartes, pianches, tabieaux, etc., peuvent stre flimbs des taux de reduction difforents.

Lorsque ie document est trop grand pour etre reproduit on un seul clichb, il est fiims a partir de l'engle supdrieur gauche, de gauche droite. ot de haut en bas, on prenant ie nombre d'images nócessaire. Les dlagrammes suivants lilustrent ia mothnde.
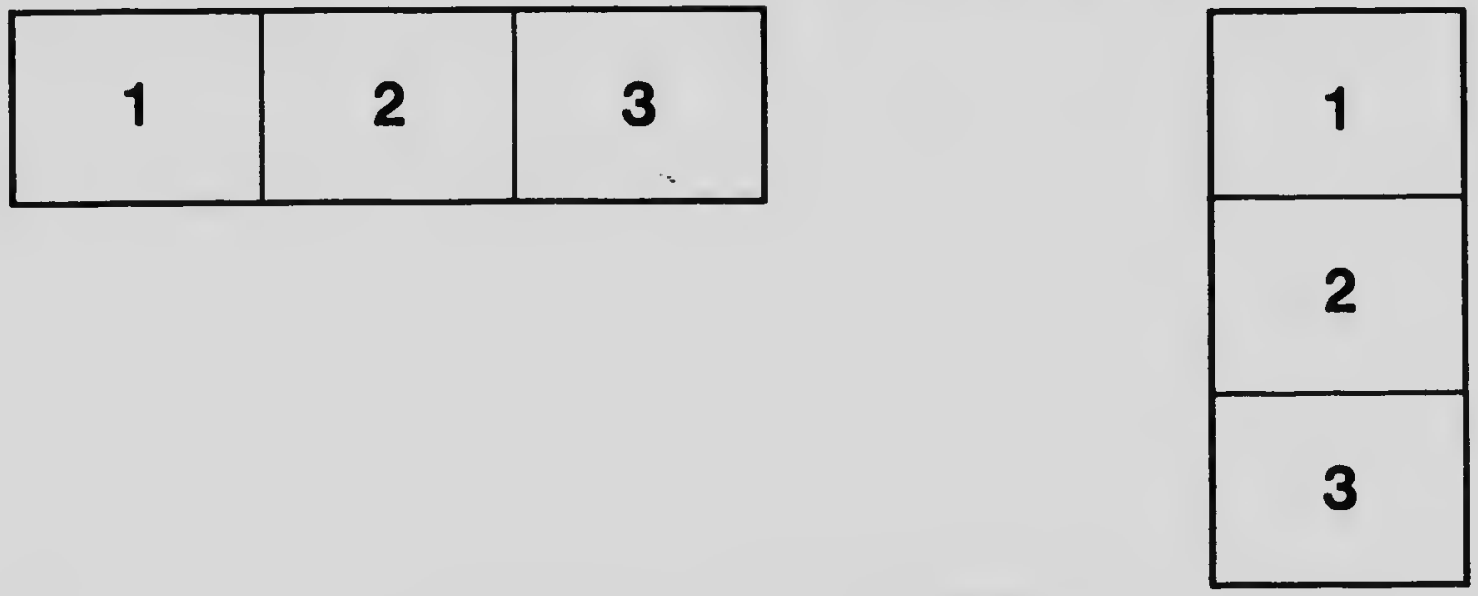

\begin{tabular}{|l|l|l|}
\hline 1 & 2 & 3 \\
\hline 4 & 5 & 6 \\
\hline
\end{tabular}


(ANSI and ISO TEST CHART No. 2)

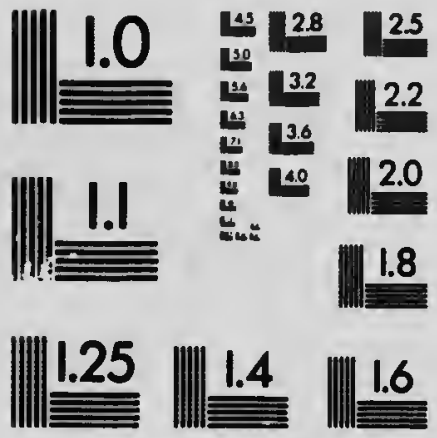

APPLIED IMAGE Inc 1653 East Main Streat

Roches'se, New York 14609 USA

(7i6) 482 - 0300 - Phone

(715) $280-5989-F a x$ 


\section{DOMINION OF CANADA \\ DEPARTMENT OF AGRICULTURE \\ ENTOMOLOGICAL BRANCH \\ C. Gcadon Hewitt, Dominion Fatomolootst}

\section{THE \\ WHITE-MARKED TUSSOCK MOTH AND ITS CONTROL \\ ON}

\section{SHADE TREES AND ORCHARD TREES}

BY

J. M. SWAINE

Assistant Entomologist, in charge of Forest

Insect Investigations

AND

C F. SANDERS

Field Officer

CIRCULAR No. 11

Published by direction of the Hon. T. A. Crerar, Minister of Agriculture, Ottawa, Ont.

OTTAWA

J. DE IABROQLERIE TACHE

PRINTER TO TIE KING'S MOST EXCIILENT MAJESTY 


\section{WE SHaLl BE PLEASED to hear from any one}

concerning damage or trouble of any kind due to insect pests. No postage is required on such letters of inquiry when addreased:

\section{DOMINION ENTOMOLOGIST,}

Denartment of Agriculture, OTTAWA, ONT.

Such inquiries should be accompanied in all cases where it is posuible by specimens of the insects. The insects should be sent packed with their food plant in a strong wooden or tin box to prevent loss in transit. Packages up to 12 ounces in weight may be mailed free and every package should bear or contain the sender's name and address and be accompanied by a letter. 
Di:P.IRTMLNT OF Acikiceltuke,

( TT:AW. January $15,1918$.

The Honourable,

The Minister of Agriculture,

Ottawa

SIR,-I have the honour to sulmit for your approval, Entomological Circular No. 11, entitled "The White-marked "Iussock Moth," which has lueen prepared under my direction by Mr. J. M. Swaire. Assistant Entomologist in charge of Forest Insect Investigations, and Mr. G. E. Sanders, Field Officer.

The White-marked Tussock Moth is one of our native insects which is widespread throughout Eastern Canada, and periodically it increases to so great an extent as to cause serious damage to the shade trees in and around our cities and towns, and to fruit in the orchards. An outbreak of this insect is now taking place in Ontario and the Maritime I'rovinces, and as usual it is causing serious apprehension in many places, with the result that we are receiving many requests for information concerning control measures. This circular has betn , :epared to meet these calls for assist ince, and not only to furnish information required by the public but also to $i_{\text {..-1 }}$-ss upon civic authorities the importance of taking steps to prevent the destı ation of their valuable shade trees by this and other insects which assist in the destruction of a feature which aclds so much to the beauty and comfort of our Canadian towns and cities.

I have the honour to be, sir.

Your oberlient servant,

\author{
C. GORDON HEIVITT, \\ Dominion Entomolonist.
}



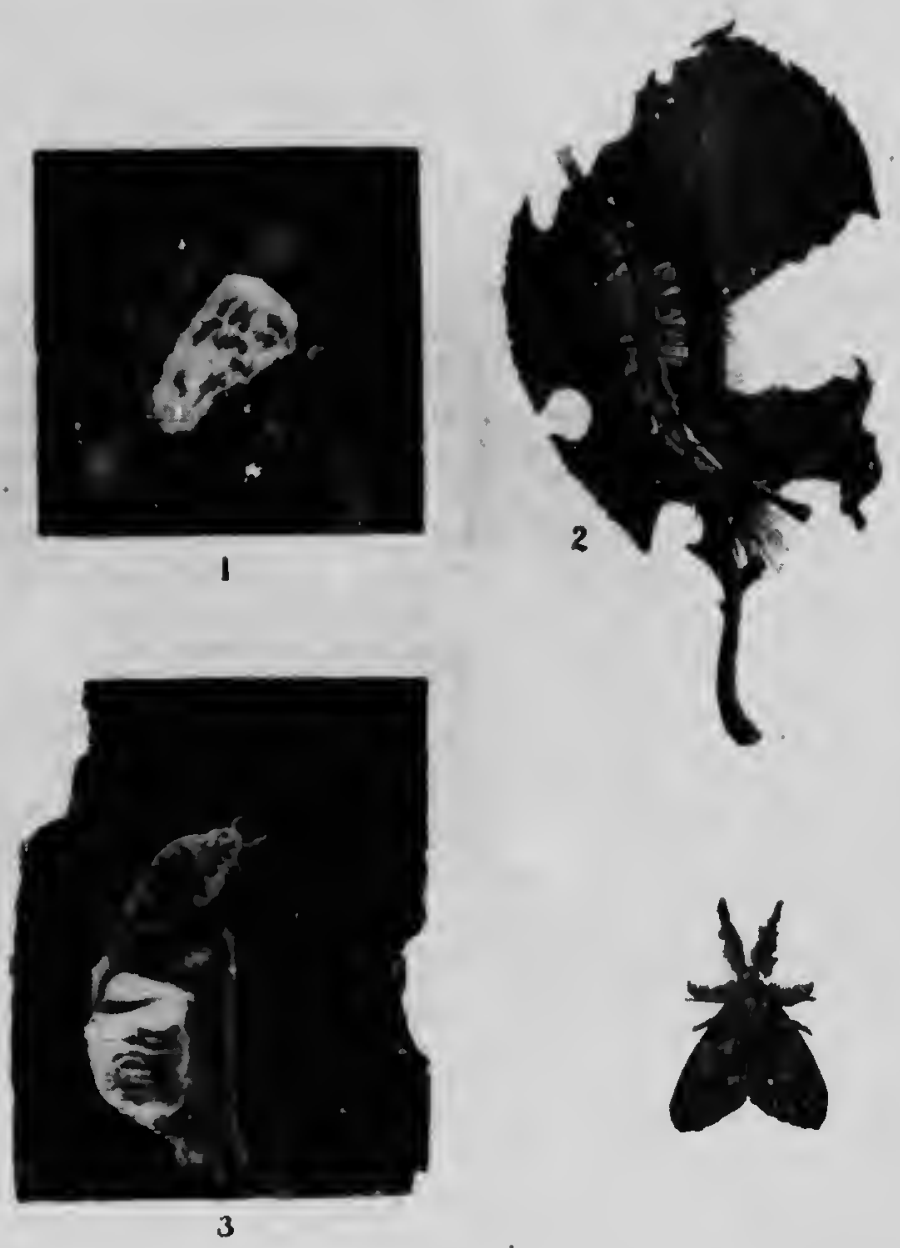

4

The Wutre-Marked Tereock.-1, an egg-mass attached to a coroun; 2, a raterpillat feeding upon a leaf: 3 , the female moth and a frohly depo-ited ege-mass: 4 , the male moth. Figs. 1, 2, and 3 are from Bul. 312 ,

Geneva Agric. Exp. Station. 


\title{
The White-Marked Tussock Moth
}

\author{
(Hemerocamine leucostigma S. \& A.)
}

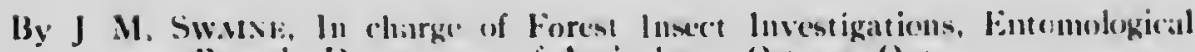

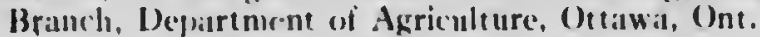

The well-known mffed caterpillars of the White-markerl Tussock Motle have been recognized for nany years as among the worst enemic's of decidnous shade trees in our eastern towns and cities. The species is a native of North America, and it is found on decidnous trees nearly everywhere each season in varying numbers. P'eriodically these caterpillars lecomle so extremely muntrous, especially about our citic's and towns, that large numbers of our finest shade trees are stripped by them, and seriously weaketied in addition to being completely disfigured by the defoliation.

The last outbreak in Fatstern Canatla occurred leetween the years 1903 and 1911, exterding from Nova Scotia to western Ontario, but affecting the tow'ls near the Great lakes, the St. Lawrence river, and the sea coast nore seriolssly than the others. Ottawa, for instance, has apparently no recoru of a serious outbreak, and egx-masses are as rare this year as usual. This very serious outbreak was finally and very suddenly brought under control by insect parasites in the sumnier of 1911, and since that time the White-marked Tussock caterpillars have been present usually in comparatively small numlers. Last season, however, the species had lecome very abundant in several towns and cities, and the numerous egg-masses now on the tree trunks indicate a severe outbreak next summer in severil places, including Moncton, Montreal, and Toronto. This species is notably a pest of cities and towns, but is injurious everywhere in times of abundance. It is an importint nemy of apple trees. since in addition to clefoliating the trees, the caterpillars reed upon and destroy the young fruit. Vigorous and properly conducted control work during the coming winter and spring will prevent the greater part of the threatened injury.

\section{DI:SCRIPTIONS OF THL: INSI:CT.}

The Adult.-The two sexes of the adult stage are - rikingly diturent appearance. The male is a leautiful grryish moth, aln 1 an inch and a across the wings when spread, with tufted legs, feathererl antennie, and trot verse wavy lines across the fore will, s.

The female, on the other hand, is a very stout and chmsy creaturc, fis wish in colour, almost without markings, and nearly wingless. She usully cr, upon the cocoon from which she has emerged, and after pairing elcposits her mass of eggs, and dies.

The Eggs. - The eggs are deposited in masses containing from one hin to five or six hundred; one egg-mass is laid by each female, usually upon empty cocoon. The mass of eggs is covered by a thick layer of white frot fluid which hardens rapidly, and, in addition to holding the eggs together. protects them from adverse wenther conditions, and in some measure probably from their enemies. The individual eggs are small, whitish, and nearly splerical The egg-masses of the closely reiated Rusty. Tussock Moth are laid bare upon the cocoon, without the frothy covering, and are thus easily rlistinguished from those of the White-marked T'ussock.

The Caterpillar. - The caterpillar of this species is perhaps as well known as any cther among our shade-tree insects, owing both th its remarkalle abundance during the outbreaks, and to the striking be:tuty of its colours and. vestiture. The length, when full-grown, is slightly more than an inch. The 
colours are in longitudinal trands, neore strongly markel behind, yel' $\mathrm{sw}$ leelow, greyish on the sides, with - bright yeliow, subdorsal band above on each sicle of a median ' 'sck band. The median dorsal lit : bears four prominent white or yellowish brushes of hair, one on each of the first four abulominal segments, and a small coral red tubercle on each of the sixth and seventh segments. The head and the upper part of the first thoracic segment are bright coral recl. Two long black pencils of plumed hairs project from the sides of the first thoracic segment over the head, and a similar pencil upwards and backwards from the median line of the eighth atxdominal segment, the twelfth including the head. The body is sparsely clothed with long, greyish hairs arising in radiating tufts from ycllowish tubercles.

The Rusty Tussock Caterpillar differs in being less brigbtly colourerl and in having a pencil of long black hairs on each side of the fourth segment lechind the head.

The Pupa.-The adult caterpillars spin greyish silken cocoons, attached usually to the bark of tree trunks. Within the cocoon the caterpillar changes its skin and appears as the chrysalis. The male chrysalis is brown or nearly black, and sparsely clothed with greyish hairs; that of the fenale is inuch larger, without the distinct wing cases, and has a transverse patch of light-coloured scales across the back of each of the first three segments behind the head. The cocoon of the female is tougher and darker in colour than that of the male.

\section{Tife Life-History axd Habits.}

The winter is passed in the egg-stage in the white conspicuuus egg-masses, attiched usually to the cocoons. Normally the egg-masses are deposited upon the trunk and the under side of the larger branches, but in seasons of great abundance they occur in considerable numbers in the u.per parts of the trees and upon nearby objects, such as fences and buildings.

The eggs hatch usually during the month of June. In very carly seisons in the district about Montreal, some egg-masses hatch in the last week of May, and the greatest activity in hatching is in the first half of June; in late seasons the greatest activity in hatching is in the last half of June, and many egg-masses remain unhatched until early in July. In Nova Scotia the eggs hatch, usually, during the last week of June. The species, therefore, remail.s in the egg-stage for practically ten months, from about the end of July until the following June, and a long period is offered for control by the removal of the egg-inasses.

The young caterpillars spread somewhat over the foliage, and feed individually on the under surface of the leaves, dropping by means of a thread of silk when disturbed. As they increase in size the wandering habit becomes more marked, and they devour the greater part of the leaf, seriously or completely defoliating the trees when their numbers are great. They complete their growth in frnro four to six weeks. Many of the large caterpillars wander about freely iree to tree, so that trees which have been previously clean may become very badly infested by them. The oller caterpillars are thus distributed locally by these wandering habits. It is probable that the small caterpillars, when suspended on the silken thread, may be carried considerable distances by winds, and the infestation still further extended in this way. When the caterpillar becomes full grown, during July or early in August, it comes to rest, normally upon the trunk or larger branches, but during an outbreak, upon any part of the tree or upon neighouring objects. H rre it spins a greyish cocoon composed of silk and hairs from the body firmly ittached to the bark or to the object upon which it rests, and within this it ch:ınges to the chrysalis or pupa. Aloout ten days or two weeks are passed in this condition, and then the adult moth appears from the cocoon. The wingl.ss female seldom moves away from the cocoon out of which she has emerged; usually she crawls upon it, and after being fertilized by a male and depositing there her whitish egg-mass, dies and 
usually falls to the ground. "I lee male cillerpillars ceave feceling an" spm their cocrons 1 irlier than the females, ancl produce distinctly sualler clirgsalitli..

The' is only one brockl annually in Eastern ('a acla, except t'. il al partial

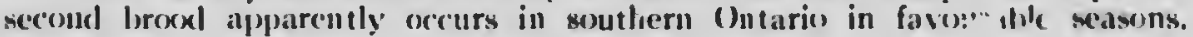

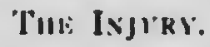

The extensive defoliation by the caterpillars destroys the leauty of tine trees for much of the season, and often injuies them so seriously that branches either clie outrigh" after repented attack, o- lecome so wakenerl therely that they gradually acumb to injury by other insects such as lorers, and fungi.

The list o rees attacked by the White-markerl " lussock includes a large IIIImlser of our sciduons shade trees, and even a few conifers. In Finstern Cilladal the fi. surite foul tree's appear ir willow, hirch, horse-chestnut, hasswook, elnıs, naples, poplars, and fruit tr "r. Felt has listed the following host-tree recorls from the Eastern Unit i ates: "linden, horse-chestnut, buckeye, maple (specially the soft and : sway), Ixselder, lioney locust, apricot, garden plum, wilil plum, garden cherry, cliokecherry, rose, pear, applf. quince, ash, clm (several species), sycamore or luttonwoul, butternut, black walnut, hickory, oak, birch, alcler, willow, poplar, spruce, fir, larch, and cypress.

\section{Niter.lt. Exi:Mtis.}

This species has a very large number of natural chemics. Minute hymenopterous parasites loreed within and destroy the eggs, al large number of hymenopterous ancl dipterous parasites kill the caterpillars an.l pupie, ancl various predaceous insects also aid in reducing their numbers. ('eriain fungi and batteria, which spreal rapilly in epidemics, elestroy great 1 umlecrs of the caterpillars, and are sometimes a chief agent in their control.

The last outbreak of the White-marked Tussock in Eastern Canladia, as already mentioned, extencled from Halifax to western Ontario, and lasterl, in all, from 1903 to 1911 it was not anywherc ahundant throughr'it the whole period, 'owever, and. : brought finally and suddenly to a close yy the action of parastu is and fungi : he species hos brel in obscurity since that time, and is just now conling ardis to prominence, since the scarcity of its parasites has allowed it to : seed to such great numbers. Eventually they will again effect its control, 11 'inuc probahly to save the life of the trees but not soon enough to prevent much injury in adclition to the disfiguration of the trees cluring the $s: 11$, ner.

few of of. native birds feed upon hairy caterpillars such as the Whitemarked Tussock, and are important factore in natural control in sections where they are still numerous. Unfortunately, man and the English sparrow have united to drive these useful birds away trom the neighourhood of our cities, tuwns, and larger villages, with the result that the White-markel Tussock and other destructive insects find our centres of population more acceptable to then than the open country. The protection and encouragement of our ir cctivorous lirrls is a most importint method of insect cuntrol.

\section{('ONTROI. MISASURLS.}

The life of city shade-trees is sufficiently precarious at the best of tiness. The almost impossible soil conditions, and the extremely adve se atnosphere content of smoke, dust, and gasses are very serious obstacler ,o healthy tree growth: and the yearly attacks by ice storms, boring insects, detoliating insects, and fungi make the life of a city-grown tree one long, or short, series of adventures.

The great value of shade trees to cities and towns is everywhere recoguized, and there should be no hesitation in naking a reasonable expenditure to protect them from those enemies which my: be suecessfully controlled. 
One of the most important methods of preventing serious insect injurie: is found in the provision of the best possible conditions for tree development. Proper surgical treatment to remove rot infections and fill the resulting cavities, and to support the weakened parts with cement, iron bolts and chains, so as to prevent breakage, as well as the provision of abundant water in dry seasons, and general precautions against injurious insects, help the trees to a vigorous condition that withstands more successfully the severe periodical insect outbreaks.

The life-history of the White-marked Tussock discloses two periods, the egg and the larval stages, during which control measures may be successfully applied. The eggs may be destroyed, and the caterpillars may be killed by poison.

THE DESTRUCTION OF EGG-MASSES.

The more effective and economical method for application in cities and towns is usually considered to be the destruction of egg-masses during the dormant season, combined with banding the tree trunks. Fortunately the white masses are so conspicuous that they are at least easily observed. The species is present in the egg-stage for practically ten months of the year, in this climate, and a long period is thus offered for the removal of the egg-masses.

If the eggs are entirely removed fron a group of trees during the fall, winter, and spring, and the trunks are properly banded to prevent reinfestation by wandering caterpillars, the foliage will be completely protected from tussock caterpillars for the season.

The egg-masses are either killed by painting them with creosote, or removed by means of wire brushes or scrapers.

Painting with Creosote.-In the control of the Gipsy Moth, the egg-masses are killed by painting them with creosote by means of a brush. This methol has also been employed successfully against the Tussock Moth egg-masses, and in some cities has replaced entirely the use of the scraper and wire brush, teing considered more effective and very much cheaper. Rubber-set paint brushes are used, attached to light pine poles, about 16 feet long and $1 \frac{1}{4}$ inches square. The creosote is darkened with lampblack so that the painted egg-masses can be more easily distinguished.

The Egg-mass Remover.-A special wire brush, 5 inches long and 1 inch wide, has proven most efficient in removing the egg-masses. A narrow hoe-blade, 6 inches long and 2 inches wide, has also been used effectively. The brush or hoe blade is attached to a long handle; two lengths may be employed, one of 10 feet and the other of 20 feet.

The work of removing or destroying the egg-masses is done usually by gangs of three men each, equipped with a 40 -foot extension ladder, and either egg-mass removers and canvas sheets or creosote outfits, one man directing the work from the ground.

When the egg-masses are removed by brush or scraper, some of them are broken and the eggs are scattered about the ground. Many of these eggs would probably survive and reinfest the trees; and it is therefore advisable to spread large canvas sheets on the ground beneath the trees before the operation so that the eggs may be easily collected, or else to have all the trees properly banded before the hatching time of the eggs in the following season.

In collecting the egg-masses, care should be taken not to remove the cocoons which do not bear the eggs. These cocoons contain useful parasites, and they should preserved; they are easily distinguished from the true egg-masses by their darker colour. The egg-masses themselves will probably contain a certain number of minute egg parasites, which would be destroyed by burning the eggs. In order to utilize the services of these beneficial insects, in seasons when egg-parasites are abundant, the egg-masses may he stored until spring, and then distributed in small, specially protected wooden boxes near the infested trees; the boxes 
should have a complete band of raupenleim or tanglefoot on the inner face of the sides near the top, so as to prevent the escape of the young caterpillars, and should be covered with wire netting. The boxes shoukl be removed after the parasites have emerged.

\section{SPRAYING WITH AISHNATHS.}

When the egg-masses have not been removed from the trees, and the caterpillars are numerous upon the foliage, it is possible to prevent further injury by spraying the trees with learl arsenate paste at the rate of 5 to 15 pouncls to 100 gallons of water. Lead arsenate is better for this purpose than Paris green, sinee it ean be used in stronger solutions without danger of serious injury to the foliage, and it adhers to the leaves for a much longer time. Five pounds of lead in one hundred gallons of water will kill the caterpillars at the time of hatching, 10 pounds of poison should be used if the caterpillars are more than a few days old, and 15 pounds after they are one-third grown. ${ }^{1}$

The first application should be made, if possible, just before the eggs hatch, or at least as soon as the caterpillars appear; the sooner they are killed the less the injury will be, and also the caterpillars are much less readily killed by poisons after they become one-third grown, or even after a few day's' feeding. Their first meal should carry the poison. See also page ...

After caterpillars have been killed by the use of poison, the trees may again become infested by the older wandering caterpillars from nearby foliage. While these may actually cause little injury to the foliage, they will spin their cocoons on the trunks and branches and infest the trees for the following season. For this reason it is necessary to band the trunks before the caterpillars begin to migrate.

As a rule it would be better to depend chiefly upon the destruction or removal of the egg-masses, during the dormant season, for control in cities and towns in moderate infestations. A very heavily infested tree is often seriously. defoliated before the spray can take effect, unless the poison is upon the leaves when the caterpillars hatch and begin to feed. The discoloration of the foliage and the houses by the spray mixtures is also an undesirable feature. When, however, the trees are very heavily laden with egg-masses, such as occurs this winter in some Ontario towns, it will be at least extremely difficult to remove all the egg-masses from all the most heavily infested trees. Under such conditions it is felt that the proper method of procedure is to clean the egg-masses completely from the less heavily infested sections of the city, and in the most heavily infested portions to remove all egg-masses from the trunks and larger branches, but without attempting to remove all from the tops. Arrangements would be made to spray these partially cleaned trees with leaci arsenate as soon as the caterpillars appear or, preferably, immediately before the eggs hatch, as well as any others which require it. The trees should all be banded with raupenleim or tanglefoot to prevent infestation from egg-masses on neighloouring fences and the buildings, if such are close at hand. Every city with many valuable shade trees to protect should own a suitalsle power-spraying outfit. With a proper equipment it would always be possible to check outloreaks of either biting or sucking insects on the foliage. The White-marked Tussock is only one of many injurious shade-trees insects.

BANDING THF; TRERS.

It has already heen pointed out that after the egg-masses or the caterpillars have been destroyerl the trunks of the trees should be bancled so as to prevent reiníestation by wanclering eaterpillars. If there is any danger of infestation

1 This rate is for application to shade trees; for use on fruit trees see page 12. The powdered form of lead arsenate is used at one-half these strengths. 


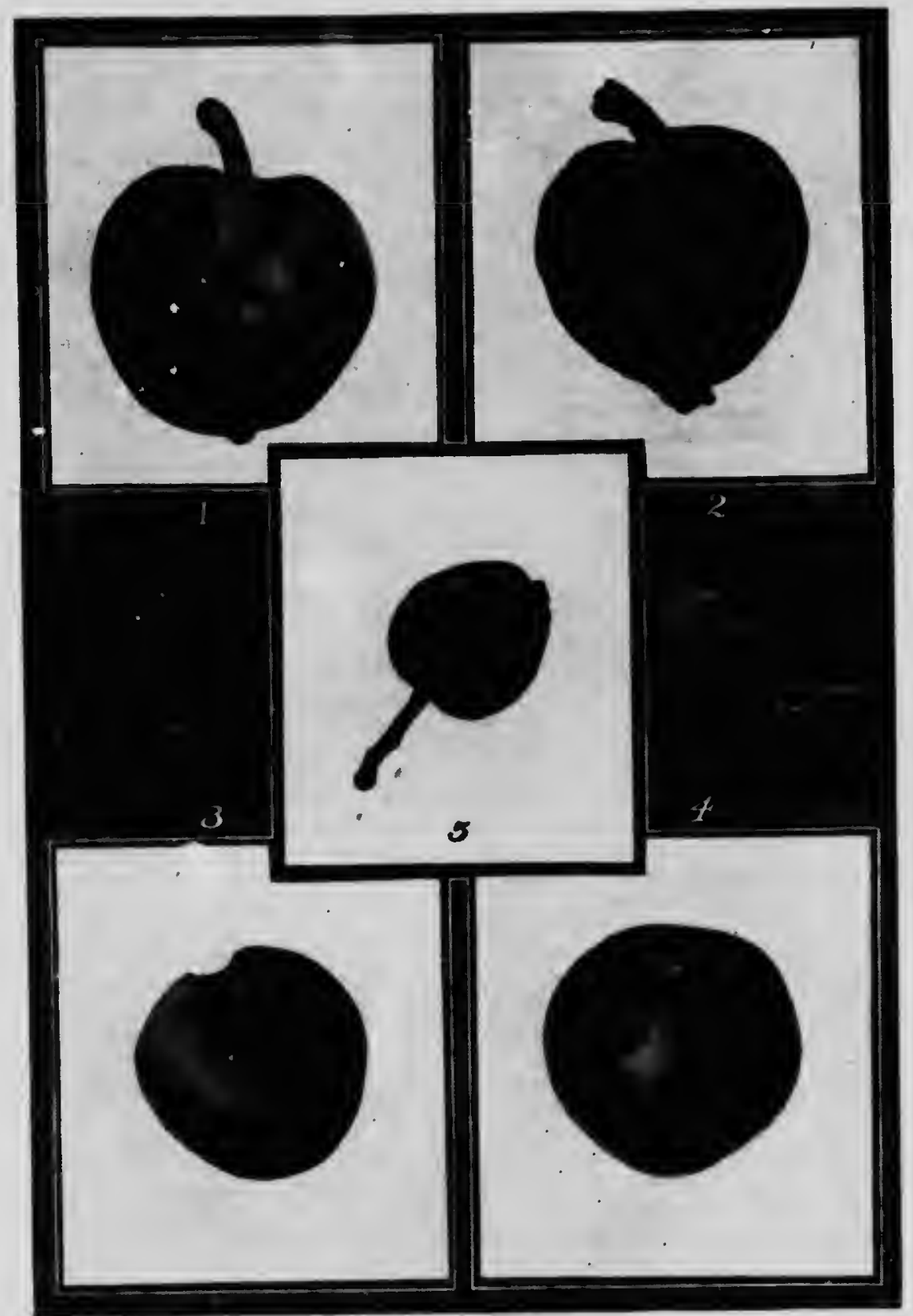

Types of injury to apples by the Whito-marked Tussock caterpillare. Fig. 5 shows the caterpillar at work. -Orisnal. 
from hatching eggs on the ground or on objects near the trees the bands should be applied before the eggs hatch, and at the latest they should be in place before the migration time of the caterpillars. The date of hatching varies so widely with the weather condicions of the season that no definite date can be recommended, but the bands should usually be in place by the middle of June, and in some seasons before that time.

Tree Tanglefoot.- Several devices for preventing the caterpillars climbing the trees, such as bands of cotton, burlap, netal, and various sticky substances, have gradually given place to the sticky mixture known as "Tree Tanglefoot," which may be obtained in bulk from any dealer in insecticides. A fair substitute may be made by boiling together equal parts of castor oil and resin.

The tanglefoot is applied with a wooden paddle so as to form a complete ring about the trunk, 4 inches wide, from 5 to 8 feet from the ground. Before the mixture is applied the surface of the trunk on which the application is to be made should be scraped unless the bark is already sufficiently smooth. The tanglefoot gradually hardens on the surface, and it is therefore advisable to break its surface by scraping it over with a coarse comb at intervals of ten days or two weeks. Instead of applying the tanglefoot to the bark it may be spread upon a strip of canvas or burlap fastened around the trunk.

When the material known as raupenleim is available, it makes the most effective band; it is more easily applied, and remains sticky for a much longer
time.

While the trees are being banded, any connections with infested locations should be broken. Telegraph wires or branches interlocking with infested trees may reinfest the clean trees after all ordinary precautions have been taken; and it is therefore necessary to band telegraph and telephone poles whose wircs have any connection with the shade trees to be protected, or to cut out with trimmers the branches which connect with the sources of infestation.

Spraying Outfit.-For spraying cicy shade irees effectively it is absolutely necessary to have an efficient spraying outfit. A power sprayer is required, capable of giving trom 400 to 600 pounds pressure, and with a pump capacity great enough so that a solid stream may be held constantly from 65 to 85 feet up from the nozzle. These requirements should be insisted upon when purchasing spu aying outfits for shade-tree work.

\section{The White-Marked Tussock Moth as an Orcilard Pest.}

By G. F. SAviers.

At intervals of from tèn to seven years, most orchards in Canada are visited by the Tussock Mioth. From one week to ten days after the blossoms fall the young larvx emerge from the egg and begin to feed on the leaves. After feeding for two weeks on the leaves the jaws become strong enough so that they can attack the fruit. From that time until they pupate, or from early July until mid-August, the larva feed on the fruit rather than on the leaves of the apple. In 1907, 1911, and 1916-17 the Tussock Moth was the most serious pest in many of the orchards of the Maritime Provinces, damaging, in some cases, as high as $\mathbf{5 0}$ per cent of the fruit. The injury to the fruit is somewhat similar to that inflicted by the Fruit Worms, but instead of a round deep bite into the fruit, the injury by Tussock caterpillars usually takes the form of long, narrow, shallow, irregular channels, which do not heal over as smoothly as Fruit Worm injury, but rather with a thick, brown, corky scab.

The larva of the White-marked Tussock emerge just before the tinie of the fourth, or last, sunımer spray, and in the past the last summer spray has been recomme.lded as the proper spray to control it. In the spraying work of 1917 it was found that from forty-four trees receiving the first spray only, 9.1 
per cent of the fruit showed Tussock injury. Fourty-four trees receiving the second or pre-blossom spray only, 6.5 per cent of the fruit showed Tussock injury. Forty-four trees receiving the third or after-blossom spray only, 4.9 per cent of the fruit ohowed Tussock injury. Forty-four trees receiving the fourti spray only, 11.8 per cent of the fruit showed Tussock injury.

These figures show how necessary $i:$ is to have the spray on the leaves before the emergence of the larvæ of biting insects from the egg, in order to get the best control, and that the residue of a spray applied two weeks befcre the emergence of the larvi is of more value in control by poisoning the larva when they eat their first meal than a spray applied at full strength two days after the larvix emerge.

For the control of outbreaks of Tussock Moth in orchards, we would recommend for the spray immediately after the hlossoms, or the Codlin Moth spray, either of the following:-

First Choice.-Standard paste lead arsenate 12 to 15 pounds to 100 gallons of water, and no fungicide; the lead arsenate at this strength is an efficient fungicide.

Second Choice.-Sodium sulphide (soluble sulphur 3 to $3 \frac{1}{2}$ pounds, Sulfocide $2-2 \frac{1}{3}$ quarts, Spra sulphur 3 pounds; arsenate of lime, $1 \frac{1}{4}$ pounds (in serious outbreaks $1 \frac{1}{2}$ to 2 pounds); hydrated or water-slaked limc, 20 to 25 pounds; water, 100 gallons.

Third Choice.-Lime-sulphur $1.006 \mathrm{sp.} \mathrm{gr.} \mathrm{or} \mathrm{two} \mathrm{gallons} \mathrm{commercial} \mathrm{con-}$ centrate to 100 gallons water. Arsenate of lime $1 \frac{1}{2}$ pounds (and in serious outbreaks, 2 pounds), to 100 gallons. (In applying lime-sulphur for the third spray, do not wet the under side of the leaves, apply the spray to the upper side). 


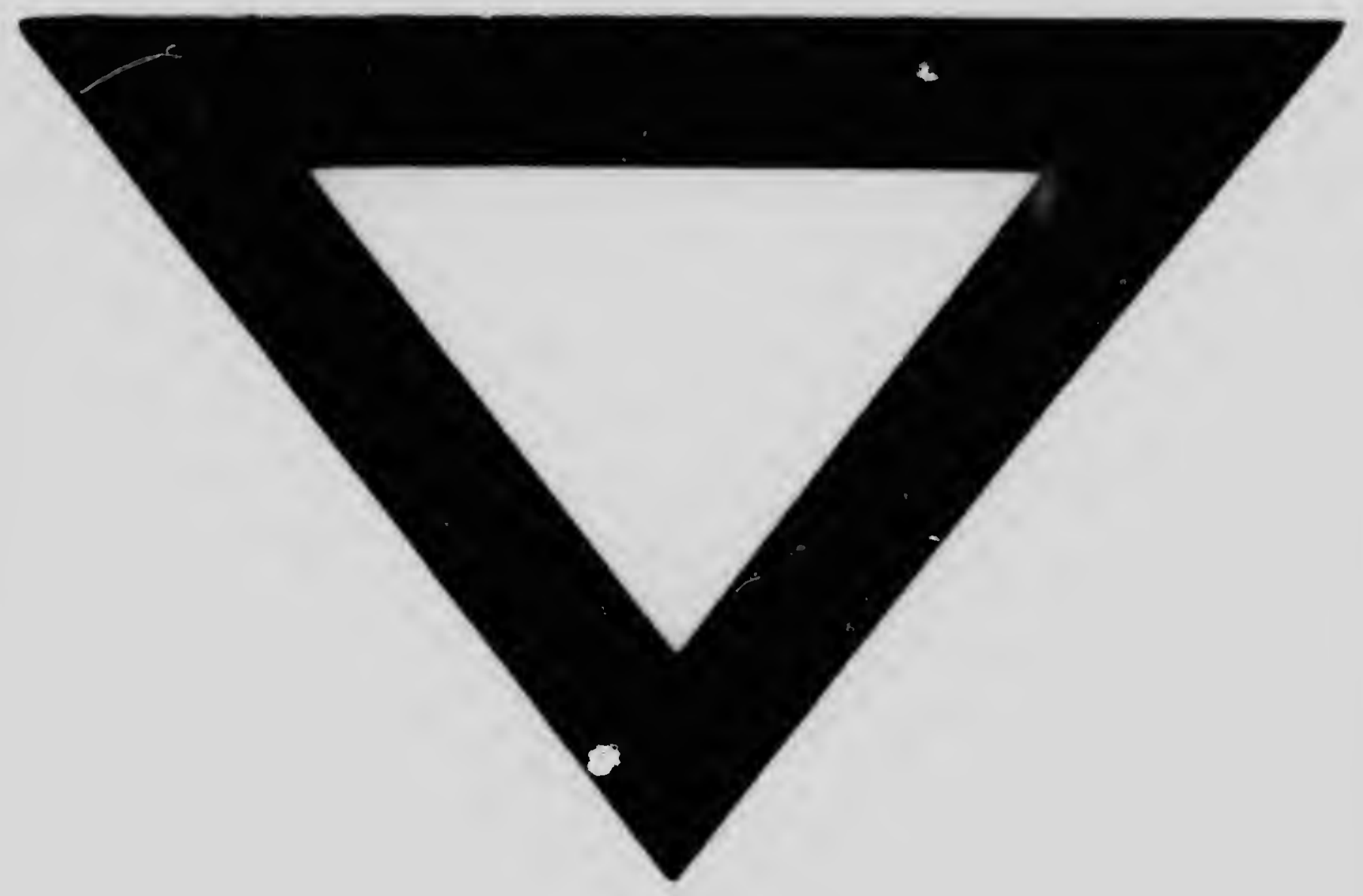

